\title{
THE READINESS OF YOGYAKARTA CITY GOVERNMENT'S EMPLOYMENT SECTOR TOWARDS THE ASEAN ECONOMIY COMMUNITY (AEC) COMPETITION IN 2016
}

\author{
AL Husni $^{1}$; Achmad Nurmandi ${ }^{2}$ \\ ${ }^{1}$ Master of Public Administration, Muhammadiyah University of Yogyakarta \\ ${ }^{2}$ Lecturer of Master of Public Administration, Muhammadiyah University of Yogyakarta \\ Email: ${ }^{1}$ alhusni.apek@gmail.com, ${ }^{2}$ nurmandi@ymail.com
}

DOI: https://doi.org/10.18196/jgpp.5193

Article Info

Article history:

Received 19 Feb 2018

Revised 01 Mar 2018

Accepted 26 Mar 2018

Keywords:

Employment Sector, AEC, Policy, Capacity Building,

Competitiveness,

ASEAN.

\section{ABSTRACT}

The ASEAN Globalization Level issues a strict commitment between ASEAN countries, regarding the agreement of the ASEAN Economic Community (AEC). The agreement that leads to competition in the various sectors, one of which focuses on the labor sector, is a major requirement in service factors. The concept of Mutual Recognition Arrangement (MRA) is an applicable norm in the recognition of skilled and certified labors. Judging at the competitiveness of the employment data availability and the growing number of Indonesian labors, then implications are made for the regions. The present research is aimed at the readiness of the Yogyakarta City Government's employment sector in the face of the ASEAN Economic Community (AEC) competition in 2016.

\section{ABSTRAK}

Tingkat Globalisasi ASEAN memberikan komitmen yang ketat pada negara antar ASEAN, mengenai kesepakatannya ASEAN Economic Community (AEC). Kesepakatan yang membawa arah pada persaingan diberbagai sektor ini, salah satu fokusnya pada sektor tenaga kerja, yang merupakan syarat utama dalam faktor jasa. Konsep Mutual Recognition Arrangement (MRA) merupakan aturan norma yang berlaku dalam pengakuan tenaga kerja yang terampil dan bersertifikasi. Oleh karenanya, dengan melihat daya

\section{INTRODUCTION}

Indonesia faces a new challenge; the challenge in the face of global competition in ASEAN Economic Community (AEC). The 
96 AEC challenges being encountered are the increasingly competitive level of trade competition, followed by competition in services and goods. Meanwhile, the Indonesia's internal challenges are the public's poor comprehension of the AEC, the regional's unreadiness in facing AEC, varying levels of regional development, and unfavorable Indonesian employment condition.

ASEAN members have embarked on economic cooperation since the validation of Bangkok Declaration in 1967. The objective of the cooperation is to accelerate economic growth, social progress, and cultural development. The ASEAN Economic Community is directed to the establishment of the ASEAN Economic Community (AEC) of which implementation is relatively faster than the cooperation in the sectors of politics-security and socio-culture. Furthermore, the agreement by the Heads of State of ASEAN, at the $9^{\text {th }}$ ASEAN Summit in Bali, known as Bali Concord II, leads to regional economic integration of which implementation refers to the AEC blueprint.

AEC Blueprint contains four main pillars: (1) ASEAN as a single market and production base, supported by elements of free flow of goods, services, investments, educated labor and more free capital flow; (2) ASEAN as an area of high economic competitiveness, with elements of competition regulations, consumer protection, intellectual property rights, infrastructure development, taxation, and e-commerce; (3) ASEAN as an area with equitable economic development with elements of Small and Medium enterprise 
development, and ASEAN integration initiatives for CMLV countries (Cambodia, Myanmar, Laos, and Vietnam); and (4) ASEAN as a fully integrated region, with the global economy alongside a coherent element of approach in economic relationship outside the region, while increasing participation in the global production networks (ASEAN Report, 2007a and ASEAN, 2013).

The number of Indonesian labors has exceeded 100 million of the total ASEAN workforce in 2008, amounted to 275.9 million. At the Meantime, in the implementation of AEC in 2015, for a detailed development of the unemployed rate in Indonesia and ASEAN, is presented below.

Figure 1.

Unemployment Rate in Indonesia and ASEAN

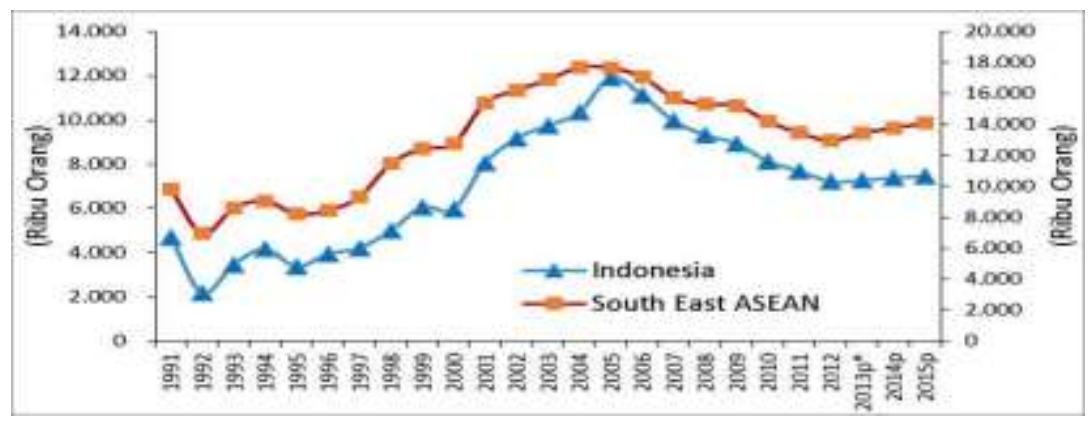

Source: International Labor Organization (ILO)

In the context of AEC implementation in 2015, one important to note is that one AEC implication is the creation of a degree of liberalization in the flow of goods and services between ASEAN countries. Nevertheless, the current movement of skilled labor migration during the implementation of the AEC is not 
completely free; instead, it remains under regulation set by a norm called Mutual Recognition Arrangement (MRA). In the MRA mechanism, the destination country will recognize the professional qualifications of skilled workers from the country of origin or sender country. The 8 MRAs are: (1) Engineering Services; (2) Nursing Services; (3) Architectural Services; (4) Surveying Qualifications; (5) Medical Practitioners; (6) Dental Practitioners; (7) Accountancy Services; and (8) Tourism Professionals.

In the face of $\mathrm{AEC}$, one important factor that needs to be prepared is the Human Resources (HR) factor or Indonesian labors. Given that one implication of AEC implementation is the occurrence of competition in the labor market, especially in the scope of ASEAN countries.

Therefore, it is necessary to conduct research on AEC Readiness in general. The present research focuses more on Yogyakarta City Government. The research leads more to labor issues, in the mechanism of Mutual Recognition Arrangement (MRA). Thus this research is aimed at "The Readiness of Yogyakarta City Government's Employment Sector in the Face of ASEAN Economic Community (AEC) Competition in 2016".

\section{LITERATURE REVIEW}

The theory used is GTZ (Deutsche Gesellschaft fur Technische Zusammenarbeit) in Milen (2006: 22), illustrating that the capacity building process has three levels that should become the focus of 
analysis and process of change within an organization. The three levels are: (1) System/ Policy; (2) Organization or Institution; and (3) Individuals/ Human Resources. It can be seen in the figure below:

Figure 2.

Capacity Development Level

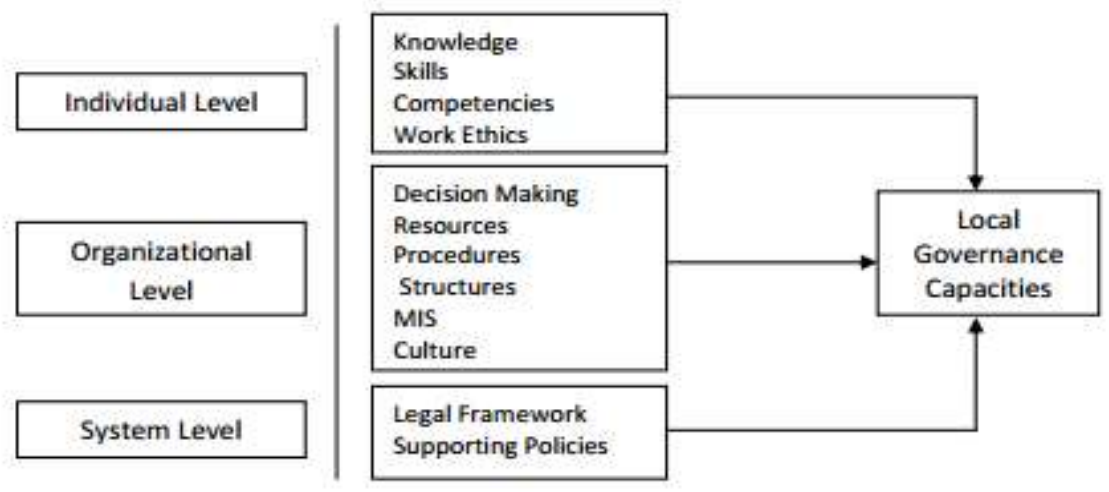

source : GTZ in Milen, 2006: 22

This division of level is done to ensure that the focus of capacity-building is in the achievement of goals effectively and determination of steps of change process operationally, thus actually achieving the desired objectives. Similar to the GTZ concept, Leavit also describes the following levels of capacity building:

1. Individual level, including: knowledge, skills, competence, and ethics.

2. Institutional level, including: resources, management, organizational structure, and decision-making system.

3. System level, including: legislation and supporting policies. 
For more details, the three levels of capacity building, according to Leavit in Djatmiko (2004), can be seen in the following figure:

Figure 3.

Capacity Development Level

Individual
I evel
Institutional
Level

System
Level

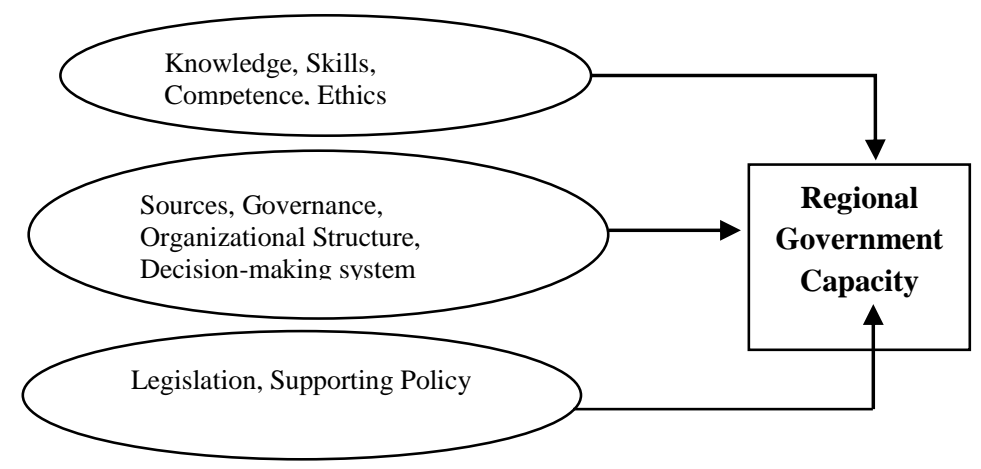

Source : Leavit in Djatmiko, 2004: 106.

In a book entitled "Hand Book of Organizations", by Arthur L. Stinchombe in March, Douglas Norton, et.al, (2003: 20) found basic variables that can be assessed to affect organizational capacity. It is explained how the organization is able to achieve its objectives properly, highly determined by the abilities of the organization to manage the social and internal environment in which it lives. Douglas concludes that organizational performance in the process is affected by organizational capacity, internal environment and the external environment: 
Figure 4.

Framework for Organizational Assessment

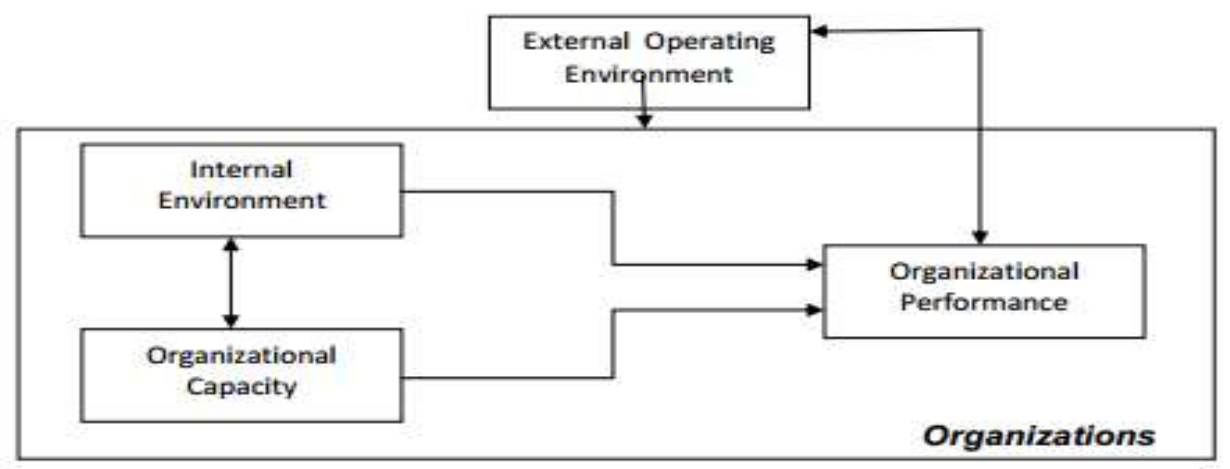

Source : Douglas Norton, et al, 2003: 20.

In relation to organizational capacity building, Leavit in Djatmiko (2004: 106), suggests that organizational capacity changes or development can be conducted through four approaches:

1. Structural Approach, emphasized on the organizational structure, especially changes in the organizational structure.

2. Technology approach, focused on the layout of new physical facilities. It is emphasized on the use and utilization of facilities and infrastructure/ technology in carrying out the work (duties and functions).

3. Task Approach, focused on job performance of individuals by emphasizing the changes and improvement of performance through effective working procedures.

4. Person approach, focusing on modification of attitude, motivation, behavior, skills acquired through training programs, selection procedures, or new equipment. 


\section{RESEARCH METHOD}

This research method employed descriptive qualitative. In the opinion of Bogdan and Taylor (1975) in Moleong (2002) in Sugiyono (2014), it was said that qualitative methodology as a research procedure that produces descriptive data in the form of written or verbal words of people and observable behavior.

The present research used data analysis technique, such as qualitative analysis, interactive analysis, and descriptive analysis of survey data. The data processing and presentation are done using SPSS test Measurement, through Cross-tabulation and "Chi Square", thus it can answer the relation between each indicator through significance value and "Symmetric Measures".

The research object was carried out in Yogyakarta City Government, especially at the Department of Cooperatives, SMEs, Manpower, and Transmigration of Yogyakarta City. The respondents of this research were the Secretary, Head of Manpower and Transmigration Development, Head of Section Development and Training of Labor Productivity, Section Head of Guidance and Placement of Manpower, Manpower Training Manager, Head of Integrated Service Center (PLUT) of Yogyakarta City, 8 MRAs in Yogyakarta City and beyond, Academics, Private sectors (Workers in the Companies), Business Actors/ SMEs, and Associated Parties.

\section{RESULT AND DISCUSSION}

\section{Capacity of Yogyakarta City Government}


The roles of the Yogyakarta City Government, particularly the Office of Cooperatives, SMEs, Manpower and Transmigration, in each capacity is affected by three indicators. It is in accordance with the theory of leavit in djatmiko (2004) used by the researcher, and the figure scheme provided by the researcher, in order to answer the readiness of the employment sector of the Yogyakarta City Government in the face of AEC. As agreed upon, there are three indicators to Measure it: the Individual level, the level of institutionalization, and system level.

Schematic drawing below explains the flow process of the discussion of each indicator and its variables on the role of Yogyakarta City Government in the face of AEC.

Figure 5.

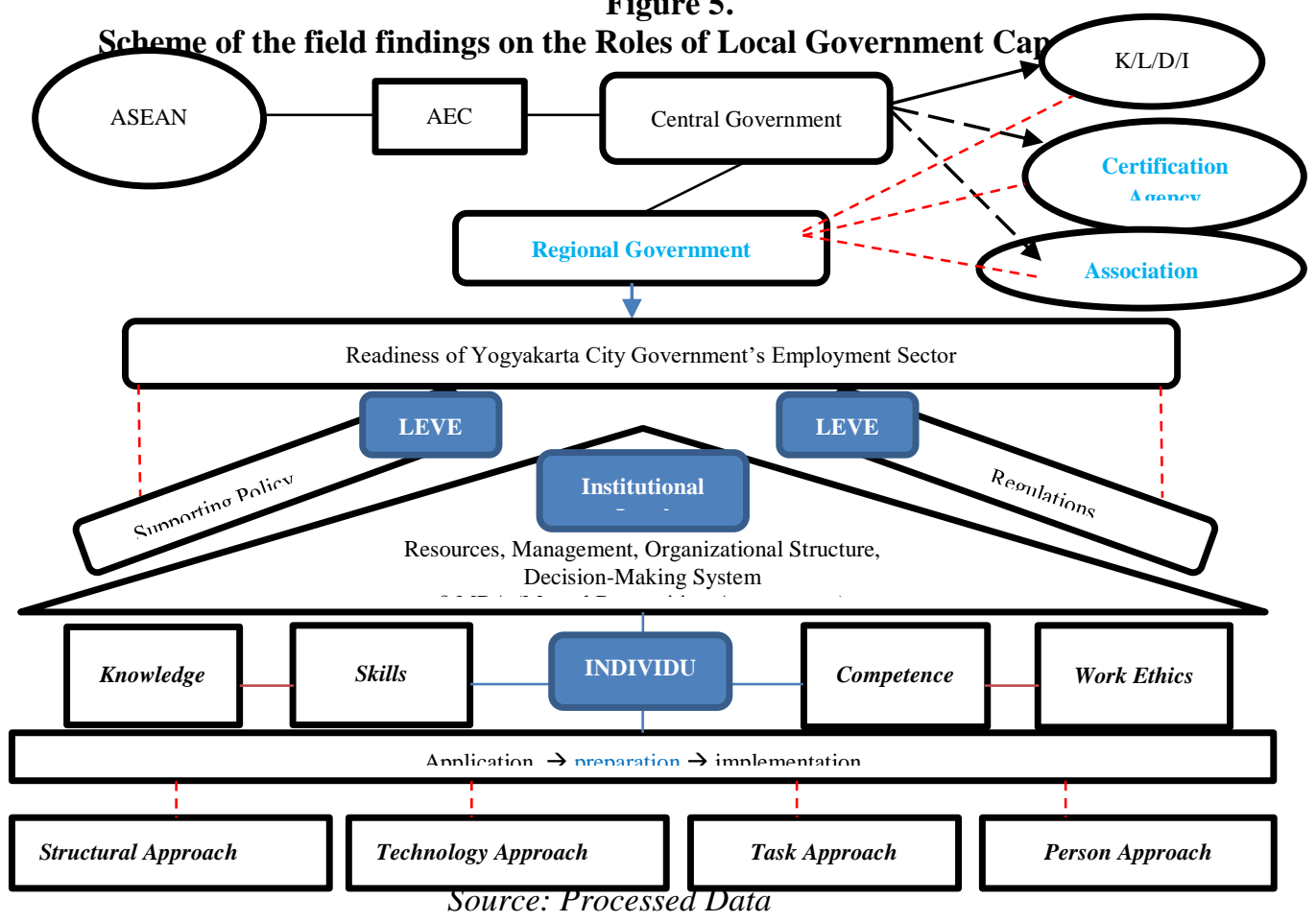


104 In order to know the capacity role of Yogyakarta City Government in facing the AEC, the respondents taken in this research are 20 people consisting of 8 people whose occupation is in accordance with MRA, 2 academics, 2 private sectors, and 8 business actors. This respondent is one of the Measuring tools of researchers in the open interview process. It is in contrast with closed-interview focusing on the research object, such as the Office of Cooperatives, SMEs, Labor and Transmigration.

It can be concluded that for the role capacity in the face of AEC, Yogyakarta City Government is ready for AEC competition which has been applied since 2015. This readiness is evidenced by the statement "agree" from the 3 categories provided. The results of the reduction are:

1. Indicator - Individual level, answered "Agreed" out of 12 people who give statement with a percentage of $58 \%$.

2. Indicator - Institutional level, answered "Agreed" from 13 people who give statements with a percentage of $66 \%$.

3. Indicator - System level, answered "Agreed" from 13 people who give statements with a percentage of $63 \%$.

a. Individual Level

Individual level is consisted of: (1) Knowledge; (2) Skills; (3) Competence; and (4) Work Ethics; in order to view the process of interrelationship between variables, namely the affecting factors with 
individual level indicators, in the roles of Yogyakarta City Government in facing AEC. The conclusions of the findings are:

1. The "agree" statement to the individual level affected by the approach:

a) 11 people answer the individual level affected by the structural approach with a percentage of 55\%.

b) 15 people answer the individual level affected by the task approach with a percentage of $75 \%$.

c) 12 people answer the individual level affected by person approach with a percentage of $60 \%$.

2. 9 respondents answer the statement "disagree" to the individual level of affected by the technological approach, with a percentage of $45 \%$ out of $100 \%$ scale, from 20 respondents.

b. Institutional Level

Institutional level consists of: (1) Resources; (2) Management; (3) Organizational Structure; and (4) Decision-Making System. The conclusion of the findings on the field is: "agree" to the individual level affected by the approach, as follows:

1. The institutional level affected by structural approach is answered by 16 people with a percentage of $80 \%$.

2. The institutional level affected by technological approach is 11 people with a percentage of $55 \%$.

3. The institutional level affected by the task approach is answered by 15 people with a $75 \%$ percentage. 
4. The institutional level affected by person approach is answered by 11 people with a percentage of $55 \%$.

It can be concluded that the "agree" percentage in overall is $66 \%$ (variable relation with indicator) which accommodates the advantages of each percentage of the approach. Therefore the institutional level will affect the existing structure, the technology used, the personnel tasks, and the persons or behaviors $\&$ attitudes.

c. System Level

The System Level comprises of Legislation and Supporting Policies. The conclusion of the findings on the field regarding the statement "agree" to the system level affected by all approaches is as follows:

1. 15 people answer system level is affected by structural approach with a percentage of $75 \%$.

2. 12 people answer system level is affected by the technological approach with a percentage of $60 \%$.

3. 11 people answer system level is affected by the task approach with a percentage of $55 \%$.

4. 12 people answer system level is affected by person approach with a percentage of $60 \%$.

Therefore, it is right on target that the role of Yogyakarta City Government in facing the AEC already is ready (the statement agreed to $63 \%$ ). It is concluded that the system level is affected by 4 approaches. It Means that the "agree" statement answers that the 
"effect" lies in all approaches within the context of the capacity role of the Regional Government.

2. Factors affecting the role of regional government capacity The findings on the field about the condition of the roles of regional government capacity are presented by the researcher below.

Figure 6.

Scheme of the Roles of Regional on the Factors affecting them Government Capacity

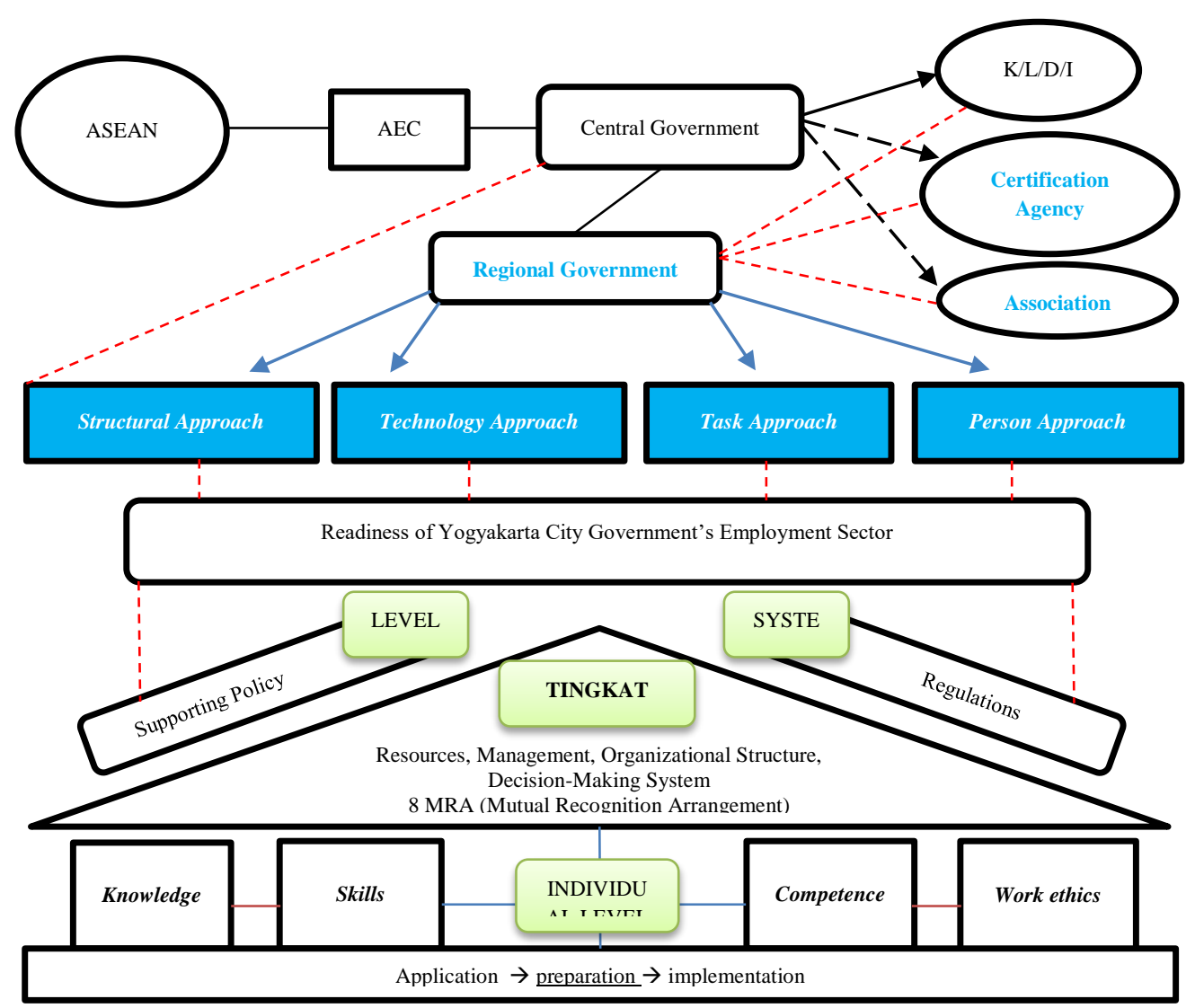

Source: Processed Data 
a. Structural Approach

For the structural approach, the researcher presents a figure scheme to explain the extent to which the structural approach plays the role of the Yogyakarta City Government in the face of AEC. The scheme is:

Figure 7.

Scheme of the Roles of Yogyakarta City Government in Structural Approach

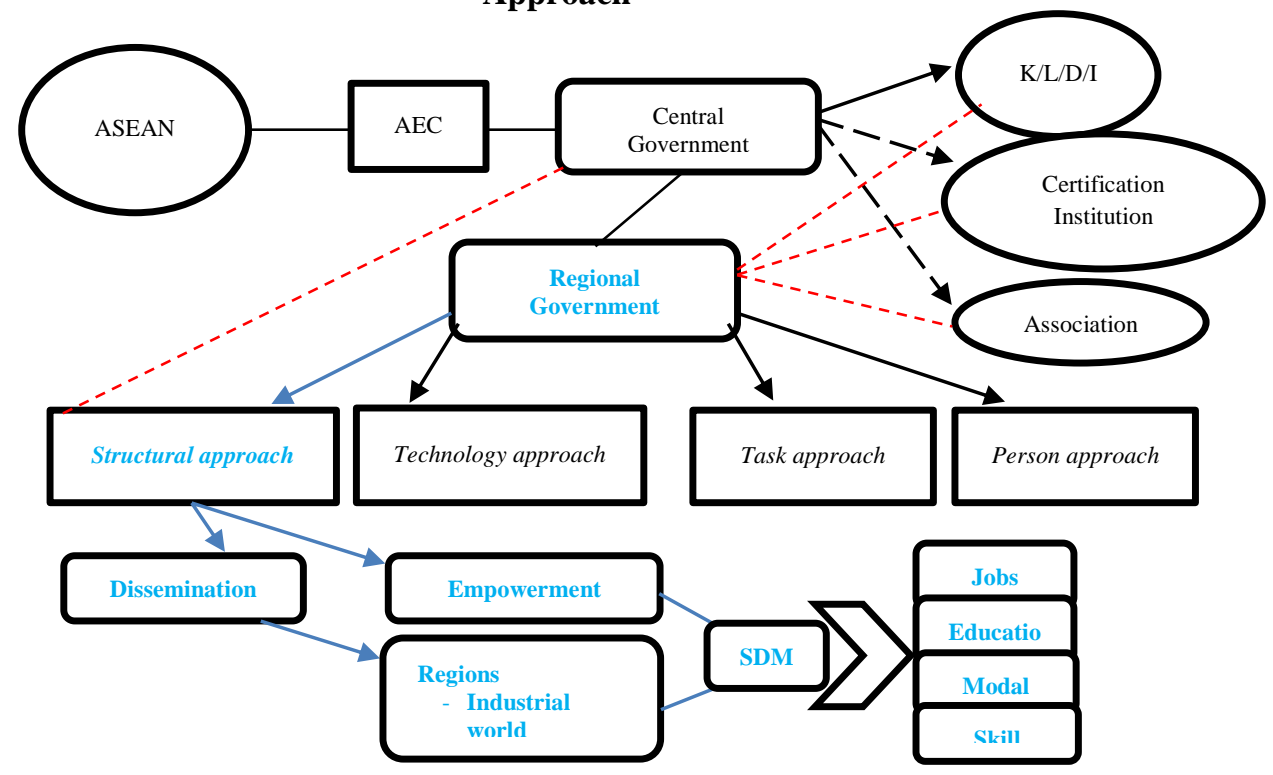

Source: processed data

From the schema above, it is clearly illustrated that the role of Regional Government is inseparable from the role of the Central Government. Furthermore, in the structural approach, as described above, the researcher concludes that:

1. Yogyakarta City Government has taken structural approach. It includes the implementation of dissemination and empowerment. The things that have been done are: (1) 
Dissemination of labor market information to the company; (2) Dissemination of AKAD, AKL, WILL TO 14 Districts; and (3) Empowerment for the Elderly (self-employment) and people in productive age.

2. To overcome the competition, the objective of dissemination and empowerment is to achieve the provision of human resources capabilities. The focus of the Industrial World is the improvement of quality/ quantity of materials, knowledgeable human resources/ basic skills, adequate budget, strategic location/ within reach for outsiders, and time for production. Meanwhile, the focus of the business world is to improve the quality of human resources, educational background, adequate capital and cooperation with relevant offices/ agencies.

b. Technology Approach

In the technological approach, it is now apparent that it is still relatively low. The lack of human resources is due to a lack of mastery of science and technology. 
Figure 8.

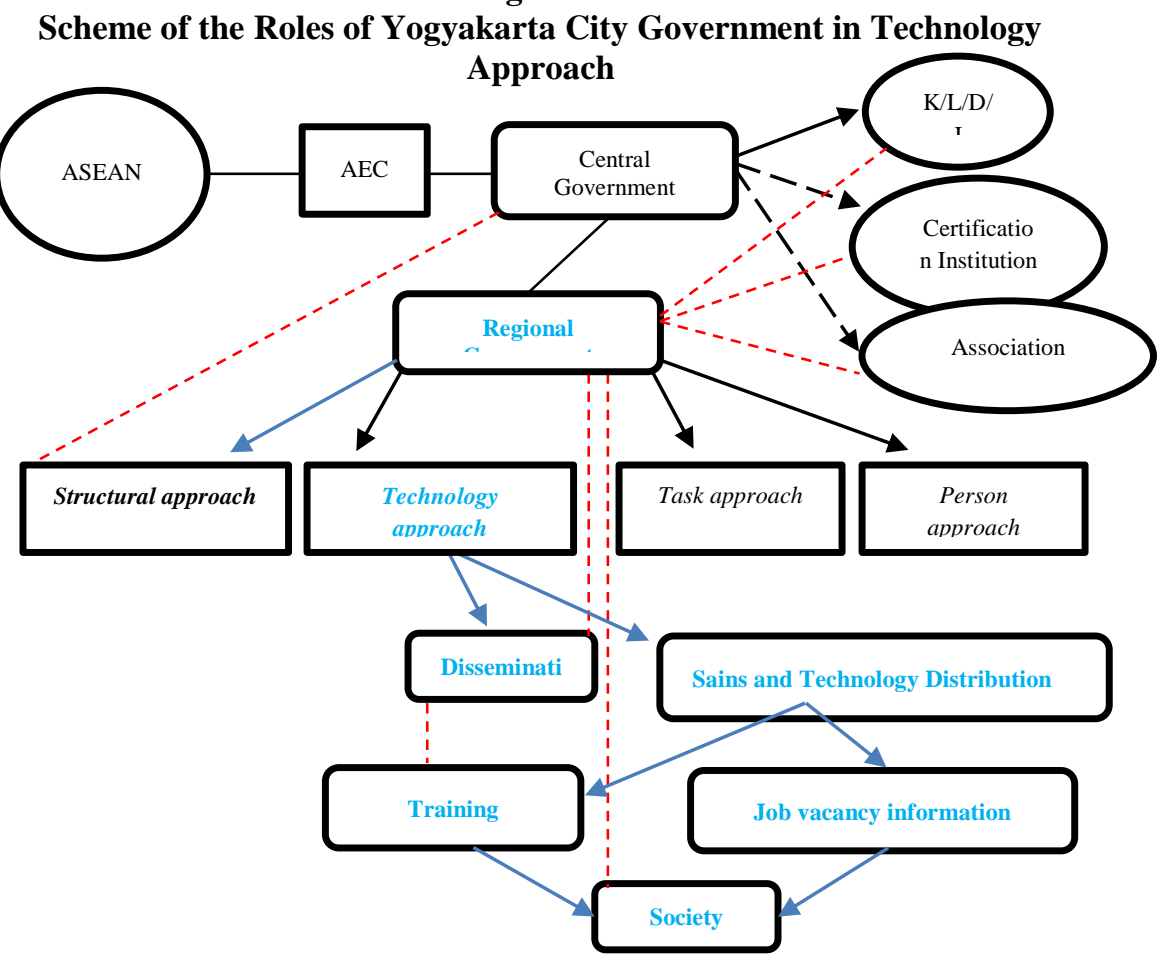

Source: processed data

The researcher concludes that Yogyakarta City Government has undertaken technology approach, implementing dissemination and distribution of science and technology. In disseminating science and technology to the people, the local government provides information and news related to the training and job vacancy information to the society.

With the presence of science and technology in this era of globalization, one cannot deny that it will bring about negative impact from various aspects in the future, be it economic, cultural and information and communication aspect. For that, filtering is 
needed in the uptake of science and technology in the future, thus optimally suppressing the negative impacts of science and technology in the improvement efforts of human resources.

\section{c. Task Approach}

This task approach is an articulation of the authority of the affairs of each work unit (the sectors) and the organization itself.

Figure 9.

Scheme of the Roles Yogyakarta City Government in Task Approach

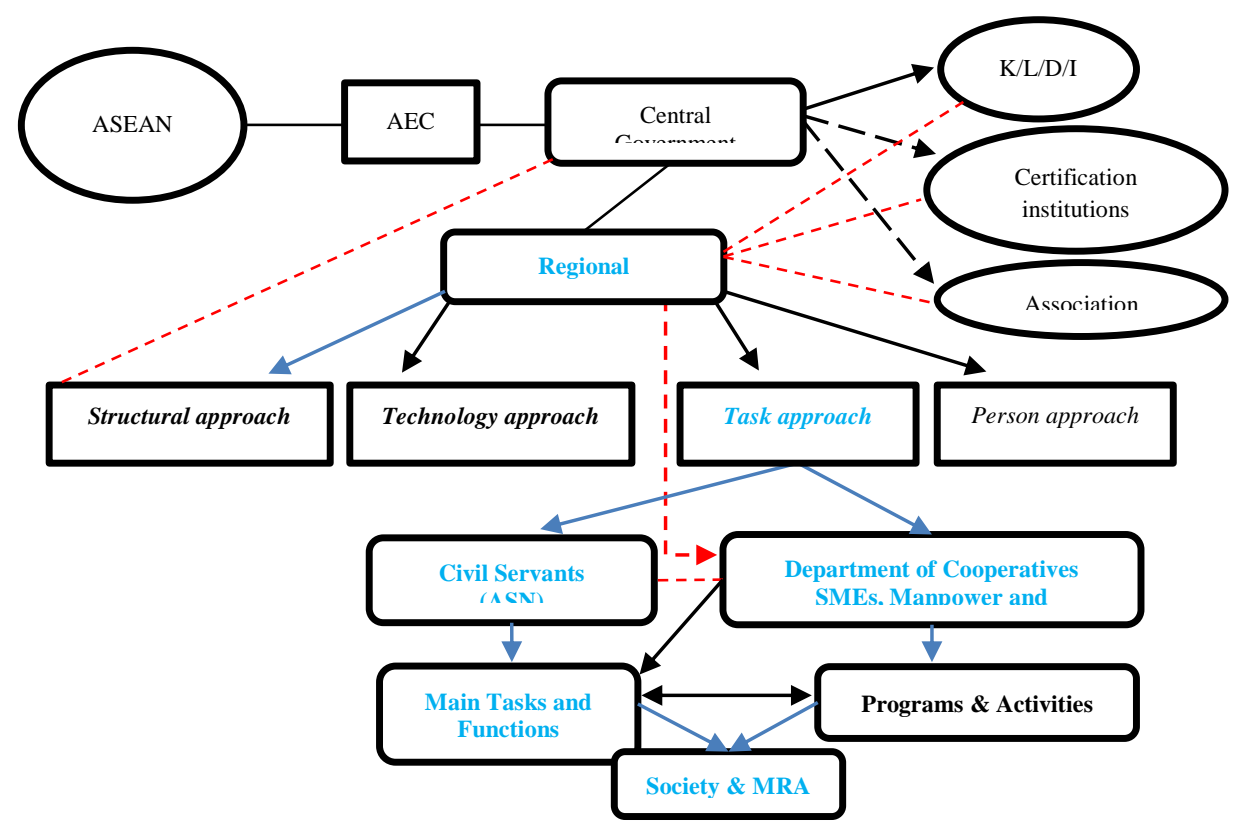

Source: Data processed

Based on the scheme above, it is clear that the role of the task approach is an obligation (implementation) that should be met by the officials or an organization. The role of duties is a mandate that must be embraced by the Regional Government of the Central 
112 Government who agreed on global competition AEC. Below, this task approach is concluded to be related to 2 things. The first is the Organization, namely the Office of Cooperatives, SMEs, Labor and Transmigration; and Second, State Civil Apparatus (ASN). Both share the role of the main task and function of the authority in the stipulated affairs. It is the basis for them to be able to do the job related to the programs and activities stipulated. Thereby, the target direction is the society. The people here are business actors and competent resources (manpower) with competency in their field to be ready and able to face the AEC.

\section{d. Person Approach}

The last affecting factor is the "Person Approach". Human Resources are one of the key factors in economic reform, i.e. about how to create qualified human resources and skills mastered. Qualified and skilled human resources must have high competitiveness in AEC global competition. In regard to this, there are at least two important things on the current condition of our human resources: (1) Inequality between the number of job opportunities and the labor force; and (2) the education level of the labor force that is still relatively low.

The problem interprets that there is a polemic and a scarcity of employment opportunities and low quality of the workforce in national level, in various sectors, and especially in the economic sector. Then, it affects the local sector. the Regional Government has a direct impact on the problem. This implication results in a sluggish 
business world, where the consequence of a prolonged economic crisis certainly leads to low employment, especially for graduates from universities. Meanwhile, on the other hand, the number of labors from college graduates category continues to increase while employment is still low. Limited employment opportunities for university graduates have impact on the increasing numbers of university graduates in Yogyakarta.

\section{SPSS Test Results, Cross-tabulation and Chi Square}

a. Linkages between Indicators

1. Individual Level Relation with Institutional Level = Significant. 11 people agree to statement - 55\%, Asymp. Sig. (2-sided) $0.029<0.05 \mathrm{HO}$ is rejected, there is a relationship. The relationship is fairly close $(0,593)$.

2. Individual Level Relation with System Level $=$ Insignificant. 8 people agree to statement - 40\%. Asymp. Sig. (2-sided) 0.454> $0.05 \mathrm{HO}$ is accepted, there is no relationship. The relationship is not fairly close (0.39).

3. Institutional Relation Level with Individual Level = Significant. 11 people agree to statement - 55\%, Asymp. Sig. (2-sided) $0.029<0.05 \mathrm{HO}$ is rejected, there is a relationship. The relationship is fairly close $(0,593)$.

4. Institutional Level relation with System Level $=$ Significant. 11 people agree to statement - 55\%, Asymp. Sig. (2-sided) 0.007 
$<0.05 \mathrm{HO}$ is rejected, there is a relationship. The relationship is very close $(0.641)$.

5. System Level Relation with Individual $=$ insignificant. 8 people agree to Statement - 40\%. Asymp. Sig. (2-sided) 0.454> $0.05 \mathrm{HO}$ is accepted, there is no relationship. The relationship is not fairly (0.393).

6. System Level Relation with Institutional $=$ Significant. 11 people agree to statement - 55\%, Asymp. Sig. (2-sided) 0.007 $<0.05 \mathrm{HO}$ is rejected, there is a relationship. The relationship is very close $(0.641)$.

b. Linkage of Parameters with Indicators

1. Individual Level

a) Relation between Knowledge Parameters and Individual Level $=$ Significant. 11 people agree to statement $-55 \%$, Asymp. Sig. (2-sided) $0.015<0.05 \mathrm{HO}$ is rejected, there is a relationship. The relationship is fairly close $(0,545)$.

b) Relation between Skill Parameters and Individual Level = Significant. 10 people agree to Statement-50\%, Asymp. Sig. (2-sided) $0.009<0.05 \mathrm{HO}$ is rejected, there is a relationship. The relationship is fairly close (0.566).

c) Relation between Parameter Competence and Individual Level $=$ Insignificant. 8 people agree to statement $-40 \%$. Asymp. Sig. (2-sided) $0.291>0.05 \mathrm{HO}$ is accepted, there is no relationship. The relationship is not fairly close (0.331). 
d) Parameter Relation between Ethical Work Ethics and Individual Level $=$ Significant. 11 people agree to statement $55 \%$, Asymp. Sig. (2-sided) $0.001<0.05 \mathrm{HO}$ is rejected, there is a relationship. The relationship is very close (0.644).

\section{Institutional Level}

a) Parameter Relation between Resource and Institutional Level $=$ insignificant. 15 people agree to Statement $-75 \%$. Asymp. Sig. (2-sided) 0.877>0.05 HO is accepted, there is no relationship. The relationship is not fairly close (0.114).

b) Parameter Relation between Management and Institutional Level $=$ Significant. 13 people agree to Statement $-65 \%$, Asymp. Sig. (2-sided) $0.015<0.05 \mathrm{HO}$ is rejected, there is a relationship. The relationship is fairly close (0.544).

c) Parameter Relation between Organizational Structure and Institutional Level $=$ Significant. 16 people agree to Statement - $80 \%$, Asymp. Sig. (2-sided) $0.002<0.05 \mathrm{HO}$ is rejected, there is a relationship. The relationship is very close (0.622).

d) Parameter Relation between Decision Making System and Institutional Level $=$ Significant. 12 people agree to Statement - 60\%, Asymp. Sig. (2-sided) $0.033<0.05 \mathrm{HO}$ is rejected, there is a relationship. The relationship is fairly close (0.504).

3. System Level

a) Parameter Relation between Legislation and System Level = Significant. 11 people agree to Statement - 55\%, Asymp. Sig. 
(2-sided) $0.016<0.05 \mathrm{HO}$ is rejected, there is a relationship. The relationship is fairly close $(0,540)$.

b) Parameter Relation between Supporting Policy and System Level $=$ insignificant. 10 people agree to Statement $-50 \%$. Asymp. Sig. (2-sided) $0.650>0.05 \mathrm{HO}$ is accepted, there is no relationship. The relationship is not fairly close (0.203).

c. Interrelationship of factors affecting the Indicators

1. Structural Approach

a) Relation between Structural Approach and Individual Level = Significant. 9 people agree to Statement - 45\%, Asymp. Sig. (2sided) $0.016<0.05 \mathrm{H0}$ is rejected, there is a relationship. The relationship is very close (0.615).

b) Relation between Structural Approach and Institutional Level = Significant. 15 people agrees to statement- 75\%, Asymp. Sig. (2-sided) $0.001<0.05 \mathrm{HO}$ is rejected, there is a relationship. The relationship is very close (0.644).

c) Relation between Structural Approach and System Level = insignificant. 8 people agree to Statement - 40\%. Asymp. Sig. (2-sided) $0.535>0.05 \mathrm{HO}$ is accepted, there is no relationship. The relationship is not very close $(0.243)$.

2. Technology Approach

a) Relation between Technology Approach and Individual Level $=$ insignificant. 6 people agree to Statement $-30 \%$. Asymp. 
Sig. (2-sided) 0.063> $0.05 \mathrm{HO}$ is accepted, there is no relationship. The relationship is fairly close $(0,556)$.

b) Relation between Technology Approach and Institutional Level $=$ Significant. 11 people agree to Statement $-55 \%$, Asymp. Sig. (2-sided) $0.007<0.05 \mathrm{HO}$ is rejected, there is a relationship. The relationship is very close (0.641).

c) Relation between Technology Approach and System Level = Significant. 10 people agree to Statement - 50\%, Asymp. Sig. (2-sided) $0.018<0.05 \mathrm{HO}$ is rejected, there is a relationship. The relationship is very close $(0.611)$.

3. Task Approach

a) Relation between Task Approach and Individual Level = insignificant. 8 people agree to statement - 40\%. Asymp. Sig. (2-sided) $0.834>0.05 \mathrm{HO}$ is accepted, there is no relationship. The relationship is not very close (0.134).

b) Relation between Task Approach and Institutional Level = Significant. 14 people agree to statement - 70\%, Asymp. Sig. (2-sided) $0.005<0.05 \mathrm{HO}$ is rejected, there is a relationship. The relationship is fairly close $(0,590)$.

c) Relation between Task Approach to System Level = Significant. 8 people agree to Statement - 40\%, Asymp. Sig. (2sided) $0.033<0.05 \mathrm{H0}$ is rejected, there is a relationship. The relationship is fairly close $(0.587)$. 


\section{People Approach}

a) Relation between Person Approach and Individual Level = Significant. 8 people agree to Statement - 40\%, Asymp. Sig. (2sided) $0.030<0.05 \mathrm{HO}$ is rejected, there is a relationship. The relationship is fairly close $(0,590)$.

b) Relation between Person Approach and Institutional Level = Significant. 11 people agree to statement - 55\%, Asymp. Sig. (2-sided) $0.020<0.05 \mathrm{HO}$ is rejected, there is a relationship. The relationship is very close $(0.607)$.

c) Relation between Person Approach and System Level = Significant. 5 people agree to Statement - 25\%. Asymp. Sig. (2sided) $0.198>0.05 \mathrm{HO}$ is accepted, there is no relationship. The relationship is not very close $(0.481)$.

\section{CONCLUSION}

Each indicator outcome is described in the previous Results and Discussions chapter. The success of each indicator has its main support from the parameters. Therefore, from the outcome of the indicator, the conclusion is First: Individual Level is not fully supported by the parameters. Although the overall individual level is in accordance with the percentage of $58 \%$, this success is not supported from HR data. The competent and internationally-certified HR data to compete in the AEC are not yet available. So far, Yogyakarta City Government only provides local (national) 
certification for the certificate issued by the agency $(\mathrm{K} / \mathrm{L} / \mathrm{D} / \mathrm{I})$ so that the community can compete in the national level. Similarly, the certificate owned by the community which is obtained directly through training institutions, and the training provided in the form of cooperation with the Government and the community itself on a regular basis.

Second: Institutional Level is fully supported by the existing parameters, of $66 \%$. The overall parameters of the institutional level are appropriate, be it in the resources (State Civil Apparatus), the management (Organization), and the organizational structure (managing sectors), and the decision-making system (implemented programs and activities, targets and achievements).

Finally, the third is the system level that is not fully supported by the parameters, although the overall system level is in line with the percentage of $63 \%$. Nevertheless, the supporting policy parameters do not have significant relationship with the system level indicator.

\section{REFERENCES}

Capacity Building. (2012). “Birokrasi Pemerintah Daerah Kabupaten/Kota Di Indonesia". Tim Peneliti STIA-LAN M akassar 2012.

Laporan Akhir Pemerintah Kota Jambi. (2016). "Analisis Kualitas Pekerja Provinsi Jambi dalam menghadapi Masyarakat Ekonomi ASEAN $(\mathrm{AEC})^{\prime \prime}$. PT. Sinergi Visi Utama, Yogyakarta.

Laporan Akhir Pemerintah Kota Balikpapan. (2015). "Penyusunan Cetak Biru Masyarakat Ekonomi ASEAN (AEC) Kota Balikpapan". PT. Sinergi Visi Utama, Yogyakarta. 
Michael G. Plummer, Peter A. Petri and Fan Zha. (2014). "Assessing the impact of ASEAN economic integration on labour markets". ILO Asia - Pasific Working Paper Series.

Monika Aring. (2015). "ASEAN Economic Community 2015: Enhancing competitiveness and employability through skill development".

Muhammad Afdi Nizar dkk. ( 2014). "Laporan Dampak ASEAN Economic Community terhadap Sektor Industri dan Jasa serta Tenaga Kerja di Indonesia".

Neil J. Smelser and Richard Swedberg. (2005). "The Handbook of Economics Sociology". Princeton University Press.

Rafaelita M. Aldaba. (2013). "ASEAN Economic Community 2015: Labor Mobility and Mutual Recognition Arrangements on Professional Services". Philippine Institute for Development Studies.

Sanchita Basu Das and et al. (2013). "The ASEAN Economic Community: a work in Progress". Singapore; ISEAS, Asian Development Bank.

Sugiyono. (2014). "Metode Penelitian Kuantitatif, Kualitatif dan R\&D". Bandung: Alfabeta.

Riset Kajian PKRB 2014. "Analisa Daya Saing dan Produktivitas Indonesia Menghadapi AEC". 